\title{
Validating Models for Calculating the Efficiency of Earth-to-Air Heat Exchangers Based on Laboratory Data for Fall and Winter 2016 in Northeastern Poland
}

\author{
Aldona Skotnicka-Siepsiak ${ }^{1 *}$, Maciej Wesołowski ${ }^{2}$, Janusz Piechocki \\ ${ }^{1}$ Institute of Building Engineering, Faculty of Geodesy, Geospatial and Civil Engineering, \\ University of Warmia and Mazury in Olsztyn, Olsztyn \\ ${ }^{2}$ Faculty of Technical Sciences, University of Warmia and Mazury in Olsztyn, Olsztyn, Poland
}

Received: 30 June 2018

Accepted: 16 August 2018

\begin{abstract}
Contemporary energy-saving mechanical ventilation systems combined with Earth-Air Heat Exchangers (EAHE) can reach high energetic and economic efficiency. The necessary condition for optimisation of ventilation system functioning is the adequate design of EAHE. This requires knowledge of soil temperature distribution in the location of EAHE. It constitutes a complex problem because of the influence of different factors. The correct estimation of soil temperature for a given location can be difficult in the designing process. The designers can rely on simplified calculation models which can, however, deviate from real empirical data. The motivation to undertake this study was to compare real, empirical energy gains with handly calculations based on two different theoretical models of soil temperature distribution. The theoretical models used for comparison were European norm and semi empirical. The laboratory setting including EAHE was located at Warmia and Mazury University in Olsztyn, Poland. Thus it can reflect real condition operations of EAHE in climate conditions of central Eastern Europe. Data were gathered in a winter period between 1 October and 31 December. The results indicate that empirical data deviate from theoretical models. Models tended to overestimate the energy gains from EAHE by $23 \%$.
\end{abstract}

Keywords: earth-to-air heat exchanger, models for calculating the thermal efficiency of earth-to-air heat exchangers

*e-mail: aldona.skotnicka-siepsiak@uwm.edu.pl 


\section{Introduction}

Mechanical ventilation and air-conditioning are indispensable for the development of energy-efficient buildings. Earth-to-air heat exchangers (EAHEs) [1] and optimized design solutions reduce costs, maximize energy efficiency and promote energy savings in buildings.

The necessary condition for optimising ventilation system functioning is the adequate design of EAHE. This requires knowledge of soil temperature distribution in the location of EAHE. It constitutes a complex problem because of different factors' influences. The correct estimation of soil temperature for a given location can be difficult in the design process. Various models for calculating the energy efficiency of EAHEs have been proposed. De Paepe and Janssens [2] have identified eight models that can be grouped based on algorithms which:

- First calculate convective heat transfer from circulating air to the pipe and then calculate conductive heat transfer from the pipe to the ground inside the ground mass.

- Only calculate convective heat transfer from circulating air to the pipe.

Both models require SOUND knowledge of the thermal properties of the ground. The Thermal Response Test (TRT) is a very popular method that supports the determination of soil thermal properties, but it can generate errors due to the influence of groundwater [3]. It should be noted that reliable analyses of soil properties directly affects the designed parameters of an EAHE, determine the system's efficiency and optimize costs [4]. The optimization of heat exchanger parameters during the design process has been widely discussed in the literature. Kumar et al. [5] relied on genetic algorithm (GA) optimization tools for design applications and soft computing methods. Cucomo et al. [6] proposed a onedimensional transient analytical model to estimate the performance of systems installed at different depths.

The motivation to undertake this study was to compare real, empirical energy gains with handly calculations based on two different theoretical models of soil temperature distribution.

Regardless of the applied tools, such as artificial neural networks [7], CFD codes [8], [9, 10] and the convolutive response factors method [11], the amount of heat transferred from the ground to ventilation air is calculated using the following formula [12]:

$$
Q=\frac{\dot{m} \cdot c_{p} \cdot\left(T_{\text {Air Out }}-T_{\text {Airl }}\right) \cdot z}{3,6}
$$

...where:

$Q$ - heat gain from the EAHE, Wh

$\dot{m}$ - mass flow rate of air $(\mathrm{kg} / \mathrm{s})$

$c_{p}$ - specific heat of air, $\mathrm{kJ} /(\mathrm{kg} \cdot \mathrm{K})$

$T_{\text {Air }[n}-$ air temperature at the EAHE inlet (ambient air) [K]
$T_{\text {Airout }}$ - air temperature at the EAHE outlet [K] $z$ - averaging interval of 1 hour

The above formula is easy to use if a full set of data relating to the performance of a ground heat exchanger is available. However, the estimations of air temperature at the EAHE outlet pose the greatest problem in evaluating a system's energy efficiency during the design process. The temperature of air at the EAHE outlet is directly linked with ground temperature, which is affected by numerous factors, including soil type and groundwater flow. Unlike the temperature of ambient air, which can be obtained from meteorological archives or estimated based on the data for a typical meteorological year, air temperature at the EAHE outlet has to be determined individually for every system. The performance of EAHEs in various locations (including Turkey [13] and India [14]) and climates (summer and winter in Chihuahua, mild climate of Mexico City, hot climate of Yucatan) [15], has been extensively researched, but most of the proposed formulas for calculating the thermal efficiency of EAHEs are based on the parameters of ambient air.

In a simplified approach, the heat output of an EAHE can be calculated with use of the following formula [16]:

$$
Q=A S \cdot U_{d} \cdot\left(T_{G}-\frac{T_{\text {Air In }}+T_{\text {Airout }}}{2}\right)
$$

...where:

$Q$ - heat transfer from the ground to the air [W]

$A S$ - surface area $\left[\mathrm{m}^{2}\right]$

$U_{d}$ - heat transfer coefficient of the air pipe $[\mathrm{W} /(\mathrm{m} 2 \mathrm{~K})]$

$T_{G}^{d}-$ ground temperature $[\mathrm{K}]$

$T_{A i r I n}$ - air temperature at the EAHE inlet (ambient air) [K]

$T_{\text {Air } O u t}-$ air temperature at the EAHE outlet [K]

According to [16], the temperature of air leaving the heat exchanger is calculated as follows:

$$
T_{\text {AirOut }}=T_{G}-\left(T_{G}-T_{A i r I n}\right) \cdot e^{\left(\frac{-U_{d} \cdot A S}{M_{\text {Air }} \cdot c p_{A i r}}\right)}[\mathrm{K}]_{(3)}
$$

...where:

$M_{A i n}$ - dry air flow rate $[\mathrm{kg} / \mathrm{s}]$

$c p_{A i r}$ - specific heat of air $[\mathrm{J} /(\mathrm{kg} \mathrm{K})]$

Ground temperature is calculated as follows:

$$
\begin{aligned}
& T_{G}=g m\left[T_{A M}-A H \cdot \Delta T_{A} \cdot \sin \left(\frac{2 \pi}{8760}(J H-V S+24,25)\right)\right]= \\
& \left.\left.=g m\left[\begin{array}{l}
T_{A M}-\left(-0.000335 \cdot h^{3}+0.01381 \cdot h^{2}-0.1993 \cdot h+1\right) \cdot \\
\Delta T_{A} \cdot \sin \left(\frac { 2 \pi } { 8 7 6 0 } \left(J H-\left(24 \cdot\left(\begin{array}{l}
-0.0195 \cdot h^{4}+0.3385 \cdot h^{3}- \\
1.0156 \cdot h^{2}+10.298 \cdot h+0.1786
\end{array}\right)\right)+24,25\right.\right.
\end{array}\right)\right)\right]
\end{aligned}
$$

...where:

$g m$ - heat transfer coefficient of soil

$T_{A M}$ - average annual temperature of ambient air $[\mathrm{K}]$ 
$A H$ - amplitude correction factor

$\Delta T_{A}$ - amplitude of annual variations in the temperature of ambient air $[\mathrm{K}]$

$J H$ - number of the hourly time interval in the year

$V S$ - curve shift

$h$ - heat exchanger depth [m]

Other methods of determining ground temperature have also been proposed in the literature. According to ASHRAE [17]:

$T_{s, z}=T_{m s}+A_{s} e^{-z \sqrt{\frac{\pi}{\alpha \tau}}} \sin \left(\frac{2 \pi\left(t-t_{\text {lag }}\right)}{\tau}-z \sqrt{\frac{\pi}{\alpha \tau}}\right)$

...where:

$A_{S}$ - surface temperature amplitude $[\mathrm{K}]$

$z-$ depth $[\mathrm{m}]$

$\alpha$ - soil thermal diffusivity $\left[\mathrm{m}^{2} /\right.$ day]

$\tau$ - length of the annual period, 365 days

$t$ - Julian date, days

$t_{\text {lag }}$ - phase lag of soil surface temperature, days

Peretti et al. [18] proposed the following formula for calculating ground temperature:

$$
\begin{aligned}
& T_{g}(z, t)=T_{m}-A_{\text {surf }} \cdot \exp ^{\left[z(\pi / 8760 \alpha)^{0.5}\right]} . \\
& \cdot \cos \left[\frac{2 \pi}{8760} \cdot\left(t-t_{0}-\frac{z}{2}\left(\frac{8760}{\pi \cdot \alpha}\right)^{0.5}\right)\right][\mathrm{K}]
\end{aligned}
$$

...where:

$T_{m}$ - average annual soil temperature [K]

$A_{\text {surf }}^{m}$ - amplitude of variations in surface temperature $[\mathrm{K}]$

$z-$ depth [m]

$\alpha$ - soil thermal diffusivity $\left[\mathrm{m}^{3} / \mathrm{h}\right]$

$t$ - time elapsed from the beginning of the calendar year in hours [h]

$t_{0}$ - phase constant of the lowest average soil surface temperature in hours from the beginning of the year $[\mathrm{h}]$

Other methods for calculating the distribution of ground temperature have also been proposed in the literature [11, 19-21].

The wide variety of models for calculating the distribution of ground temperature has prompted the authors to search for a model that has been experimentally validated in the Polish climate. In this study, the heat output of an EAHE installed in Olsztyn, determined based on experimental data for the winter season, was compared with the theoretical handly calculation heat output of the same EAHE based on a semi-empirical formula describing ground temperature distribution in the regions of Białystok [22] and Poznań [23].

In the adopted model, ground temperature at depth $\mathrm{x}$ was determined as follows:

$$
\begin{gathered}
T(x, t)=\left(T_{m}+\Delta T_{m}\right)-1.07 k_{v} A_{s} \cdot \\
\cdot \exp \left(-0.000315625 \cdot x \cdot a^{-0.5}\right) \cdot \\
\cdot \cos \left[\frac{2 \pi}{365}\left(t-t_{O}-0.018335 \cdot x \cdot a^{-0.5}\right)\right]
\end{gathered}
$$

...where:

$a=60 \cdot 10^{-8}-$ average soil thermal diffusivity $\left[\mathrm{m}^{2} / \mathrm{s}\right]$

$A_{S}=12.1$ - annual amplitude of average monthly air temperature $[\mathrm{K}]$

$k_{v}=0.85-$ vegetation index under the turf

$t$ - day of the year, in days

$t_{0}$ - phase shift of the annual amplitude of ground temperature, in days

$T_{m}$ - average annual temperature of ambient air $\left[{ }^{\circ} \mathrm{C}\right]$

$\Delta T_{m}-$ deviation of ground temperature below the shallow zone $\left[{ }^{\circ} \mathrm{C}\right]$

$x$ - depth below ground surface [m]

The formula is modified as follows to account for the depth of heat exchanger pipes buried in the ground:

$$
\begin{aligned}
& T(x, t)=A-1.07 k_{v} \cdot A_{s} \exp \left(-0.000315625 \cdot x\left(\frac{1}{a}\right)^{-0.5} \cdot B\right) . \\
& \cdot \cos \left[\frac{2 \pi}{365}\left(t+C-0.018335 \cdot x\left(\frac{1}{a}\right)^{-0.5} \cdot B\right)\right]
\end{aligned}
$$

... and the coefficients take on the following values:

$$
A=10.660849-0.075308556 \cdot(\ln x)^{2}
$$

$$
B=1 /\left(1.153317-0.15654024 \cdot x+0.049820926 \cdot x^{1.5}\right)
$$

$C=-18.744084+0.25682152 \cdot x^{2}-0.04096958 \cdot x^{3}$

Due to the unavailability of experimental data, the values of parameters $a$ and $A_{s}$ were based on the data for Białystok [22], which is closer to Olsztyn than Poznań. In view of the location of the analyzed EAHE, the vegetation index under the turf was adopted at $k_{v}=1.85$, but a formula for calculating the vegetation index under a car park was also presented for the city of Poznań [23]:

$k_{v}=1.2957+0.24046 \exp \left(-0.5 \cdot(|t-228.91| / 3.0676)^{3.0676}\right)[-]$

The influence of ground cover on temperature distribution below the surface was also recognized by Mihalakakou, Lewis and Santamouris [24], who observed that the absence of grass cover increased the system's heating capacity.

In this study, the analyzed EAHE was used to heat ambient air in winter in Central Europe. The application of ground heat exchangers to lower the temperature of ambient air in summer $[25,26]$ and the efficiency of 
such solutions [27] have been thoroughly discussed in the literature. The construction of EAHA is constantly improved [28].

The problems of EAHA thermal design are commonly undertaken and widely investigated by different authors. Factors such as ground thermal properties and undisturbed ground temperature are included as having an important influence in designing EAHA exchangers, for example by Aresti, Christodoulides and Florides [29]. Rouag, Benchabane and Mehdid [30] proposed a new developed semianalytical method in which the temperature distribution in the soil near the EAHE is studied. Thanks to that, it is possible to determine the soil radius as a function of the operation duration. Apart from this radiation, any additional thermal impact of exchanger duct was not observed. This research method is meant to estimate the worsening of EAHE parameters in time.

Other interesting research done by Yusof et al. [31] included the creation of a laboratory setting that allows for complete imitation of thermal operation of EAHA. The construction of a simulator allowed for avoidance of typical problems of field research, namely limitations in rapid changes of input parameter and repeatability. Estrada et al. [32] stress the necessity of including latent heat exchanges in EAHE design.

Ground temperature distribution is also an important consideration in other engineering applications such as borehole heat exchangers [33] and heat pumps [34].

All symbols in formulas 1-12 are as in original papers.

\section{Laboratory Station}

The laboratory station comprised the Awadukt Thermo system of ground-coupled pipes buried in the ground at a depth of $2.10 \mathrm{~m}$ at the point of intersection with the building's cellar wall to $2.28 \mathrm{~m}$ by the rainwater tank. The pipes had a downward slope in the direction of the rainwater tank in the vicinity of the AwaduktThermo air inlet tower. The pipeline had a total length of $41 \mathrm{~m}$, with an external pipe diameter of $0.2 \mathrm{~m}$ and four $90^{\circ} \mathrm{C}$ elbow pipes. The measuring system comprised resistance temperature detectors mounted on the external northern wall of the building and by the EAHE outlet supplying air to the ventilation unit. In the EAHE, the air flow rate was measured with a detector installed inside the pipeline by the inlet to the ventilation unit in the cellar. The measurements were registered by a Siemens controller in real time and were averaged in hourly intervals. The airflow rate was around $152.05 \mathrm{~m}^{3} / \mathrm{h}$, and the flow rate inside the EAHE was around $1.44 \mathrm{~m} / \mathrm{s}$ during the experiment.

\section{Results}

The analyzed data covered a period of three months (October to December) in 2016. In the evaluated period, weather conditions consistent with a typical meteorological year (TMY) were observed over 2208 hours. A total of 2051 hours during which air temperature was consistent with the TMY database were obtained in laboratory measurements (5 days were not registered due to technical problems), and all calculations were performed for the above number of hours for comparative purposes.

The analyzed period was characterized by higher temperatures than those indicated in the meteorological database (Fig. 2). The average temperature of ambient air was $4.2^{\circ} \mathrm{C}$ in laboratory measurements and $2.6^{\circ} \mathrm{C}$ in the TMY database. The minimum temperature of ambient air was $-5.8^{\circ} \mathrm{C}$ in the experiment and $-7.7^{\circ} \mathrm{C}$ in the TMY database, and the maximum temperature was $17.7^{\circ} \mathrm{C}$ and $16.2^{\circ} \mathrm{C}$, respectively. The most frequently registered

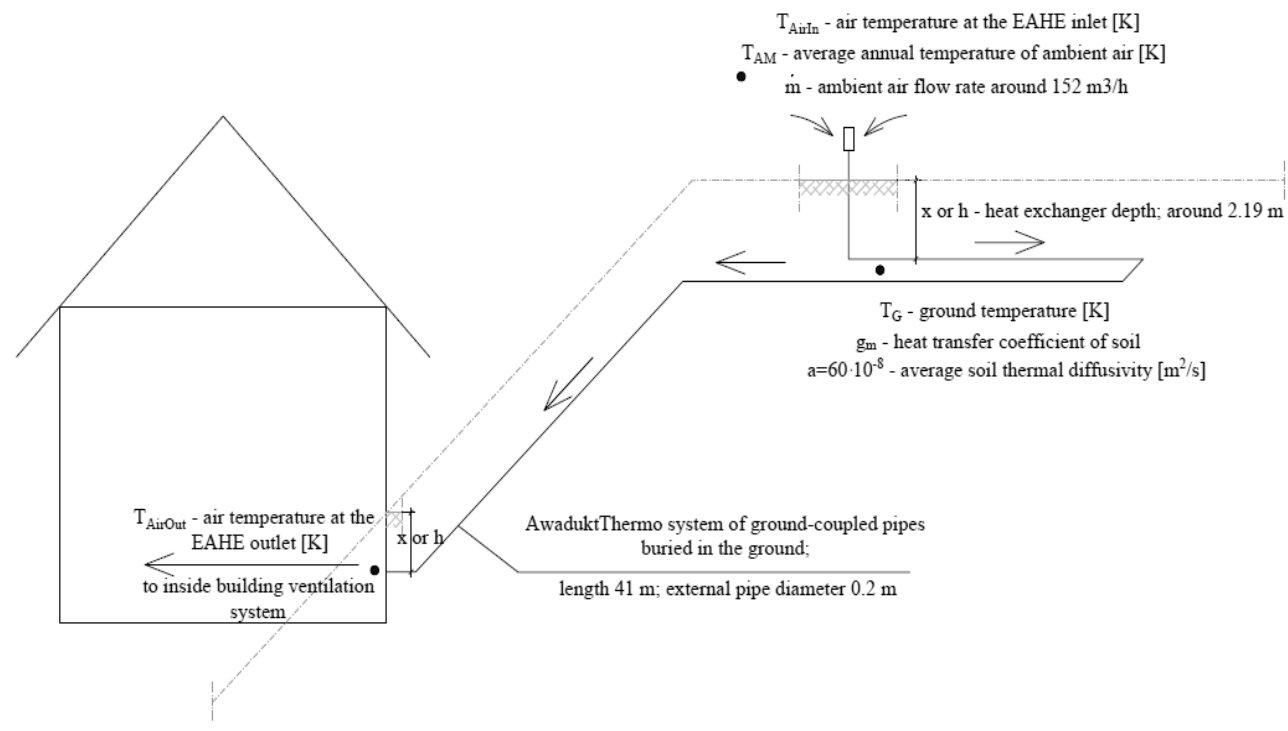

Fig. 1. The scheme of research installation (source: own elaboration). 


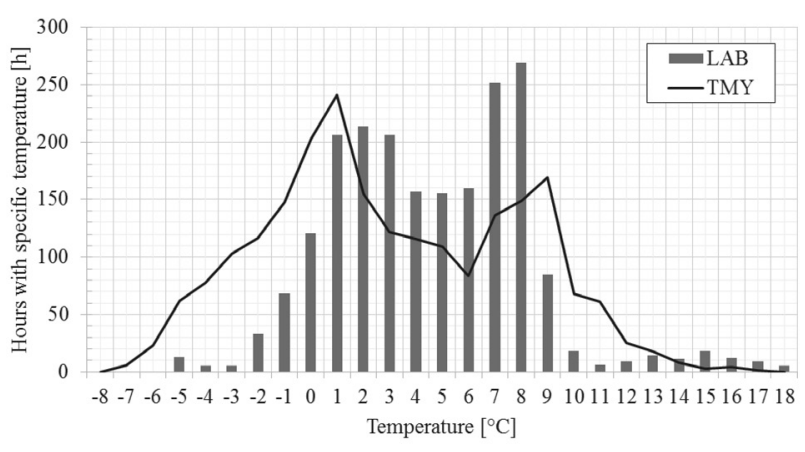

Fig. 2. Distribution of air temperatures between October and December 2016 in Olsztyn based on the performed measurements and a meteorological database (TMY) (source: own elaboration).

temperature in the evaluated period was around $8^{\circ} \mathrm{C}$ in the experiment (269 hours) and around $1{ }^{\circ} \mathrm{C}$ in the meteorological database (241 hours). Calculations were performed for the five cases presented in Table 1.

In case 1 , the thermal efficiency of the EAHE was calculated based on the temperatures measured at the EAHE inlet and outlet. In case 2, thermal efficiency was modeled according to Standard PN-EN 15241:2011 based only on the measured temperatures of ambient air. In case 3 , thermal efficiency was calculated according to the model proposed by [23] with the use of formulas (811) based on the measured temperatures of ambient air. In case 4, thermal efficiency was determined according to the theoretical model stipulated in Standard PN-EN 15241:2011 based on TMY data. In case 5, thermal efficiency was determined according to the model proposed by [23] based on TMY data.

The average hourly temperature at the EAHE outlet was $9.88^{\circ} \mathrm{C}$ in the experiment (Fig. 3). The minimum value of the above parameter was determined at $3.88^{\circ} \mathrm{C}$ and the maximum value at $18.44^{\circ} \mathrm{C}$. These results indicate that ground temperature significantly influences the temperature measured at the EAHE outlet. Minor daily variations in the temperature of ambient air were noted at $1.5 \mathrm{~K}$ on average. The results of the calculations based on both experimental data and TMY data revealed that air temperature at the EAHE outlet was almost equal to ground temperature (Fig. 2). The above

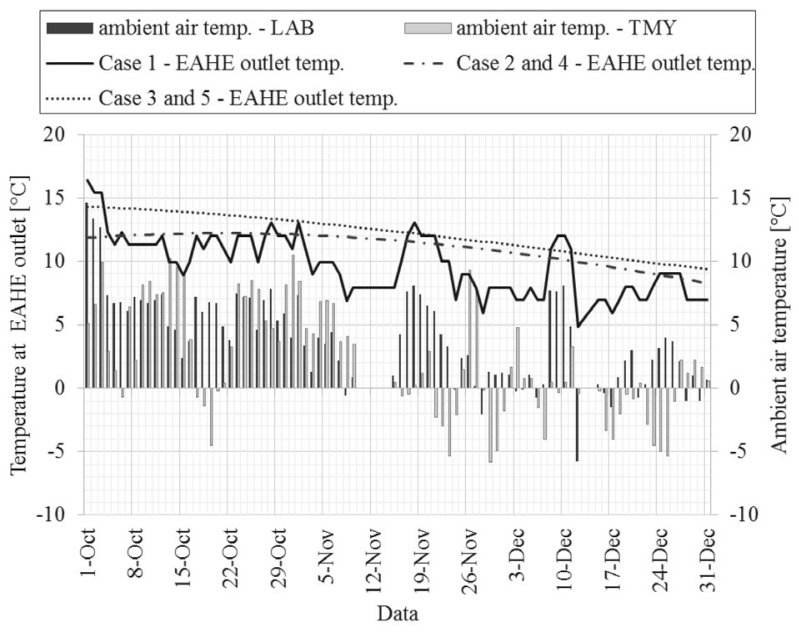

Fig. 3. Temperature distribution at the EAHE outlet in the analyzed cases relative to the distribution of the measured temperatures and temperatures from the meteorological database (source: own elaboration).

explains similar outlet temperatures in cases 2 and 4 . A similar correlation was noted in cases 3 and 5 . In cases 2 and 4, the hourly temperature of ambient air at the EAHE outlet was $11.09^{\circ} \mathrm{C}$ on average, the minimum temperature was $8.25^{\circ} \mathrm{C}$, and the maximum temperature was $12.21^{\circ} \mathrm{C}$. In cases 3 and 5 , the average hourly air temperature at the EAHE outlet was $12.18^{\circ} \mathrm{C}$, the minimum temperature was $9.37^{\circ} \mathrm{C}$, and the maximum temperature was $14.32^{\circ} \mathrm{C}$.

In case 1 (laboratory experiment), the average hourly difference between inlet and outlet temperature was $5.72^{\circ} \mathrm{C}$. The minimum hourly difference in temperature was $0.32^{\circ} \mathrm{C}$, and it was registered on 2 October at around 13:00. The maximum hourly difference in temperature was $11.12^{\circ} \mathrm{C}$, and it was registered on 13 December around $06: 00$. In case 2 , the average hourly difference between inlet and outlet temperature was $6.93^{\circ} \mathrm{C}$. The minimum hourly difference in temperature was $-5.81^{\circ} \mathrm{C}$ (cooling), and it was registered on 2 October at around 14:00. The maximum hourly difference in temperature was $15.71^{\circ} \mathrm{C}$, and it was registered on 22 December around 22:00. In case 3, the average hourly difference

Table 1. Case study (Source: own elaboration).

\begin{tabular}{|l|c|c|}
\hline & $\begin{array}{c}T_{\text {Airl }}-\text { air temperature at the EAHE inlet } \\
\text { (ambient air) }[\mathrm{K}]\end{array}$ & $T_{\text {Air } \text { out }}-$ air temperature at the EAHE outlet [K] \\
\hline Case 1 & Laboratory data & Laboratory data \\
\hline Case 2 & Laboratory data & $\begin{array}{c}\text { Based on formula (3) where ground temperature is determined according to } \\
\text { standard PN-EN 15241:2011 (formula 4) }\end{array}$ \\
\hline Case 3 & Laboratory data & $\begin{array}{c}\text { Based on formula (3) where ground temperature is determined according to [23] } \\
\text { (formulas 8-11) }\end{array}$ \\
\hline Case 4 & TMY & $\begin{array}{c}\text { Based on formula (3) where ground temperature is determined according to } \\
\text { standard PN-EN 15241:2011 (formula 4) }\end{array}$ \\
\hline Case 5 & TMY & $\begin{array}{c}\text { Based on formula (3) where ground temperature is determined according to [23] } \\
\text { (formulas 8-11) }\end{array}$ \\
\hline
\end{tabular}




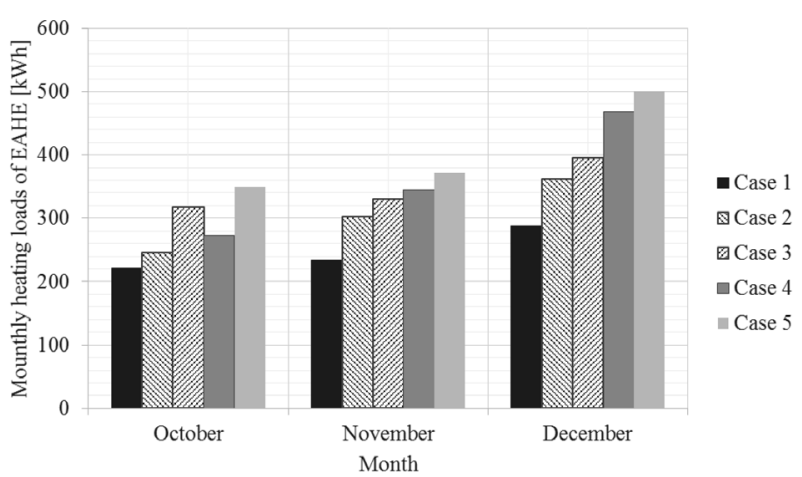

Fig. 4. Monthly heating loads of the ground heat exchanger [kWh] (source: own elaboration).

between inlet and outlet temperature was $8.30^{\circ} \mathrm{C}$. The minimum hourly difference in temperature was $-2.76^{\circ} \mathrm{C}$ (cooling), and it was registered on 2 October around 14:00. The maximum hourly difference in temperature was $16.43^{\circ} \mathrm{C}$, and it was registered on 23 December around 23:00. In case 4, the average hourly difference between inlet and outlet temperature was $8.23^{\circ} \mathrm{C}$. The minimum hourly difference in temperature was $-4.28^{\circ} \mathrm{C}$ (cooling), and it was registered on 3 October around noon. The maximum hourly difference in temperature was $17.95^{\circ} \mathrm{C}$, and it was registered on 24 November around 23:00. In case 5, the average hourly difference between inlet and outlet temperature was $9.32^{\circ} \mathrm{C}$. The minimum hourly difference in temperature was $-1.93^{\circ} \mathrm{C}$ (cooling), and it was registered on 3 October around noon. The maximum hourly difference in temperature was $18.82^{\circ} \mathrm{C}$, and it was registered on 20 October around midnight.

In the laboratory experiment (case 1) (Fig. 4), the heat gains from the analyzed EAHE were determined at $221.44 \mathrm{kWh}$ in October, $233.92 \mathrm{kWh}$ in November and $288.46 \mathrm{kWh}$ in December. The average hourly heat gain was $0.36 \mathrm{kWh}$. The maximum hourly heat gain was $0.74 \mathrm{kWh}$ (13 December at 06:00). Air cooling was not observed. In case 2 , heat gains were $10 \%$ higher in October, 23\% higher in November and 20\% in December. Air was cooled for 74 hours (cooling load of $-11.59 \mathrm{kWh}$ ). In case 3 , heat gains were $30 \%$ higher in October, 29\% higher in November and 27\% higher in December. Air was cooled for 38 hours (cooling load of $-3.19 \mathrm{kWh}$ ). In case 4 , heat gains were $19 \%$ higher in October, 32\% higher in November and 38\% higher in December. Air was cooled for 34 hours (cooling load of $-2.80 \mathrm{kWh}$ ). In case 5, heat gains were $37 \%$ higher in October, $37 \%$ in November and $42 \%$ in December. Air was cooled for 9 hours (cooling load of $-0.51 \mathrm{kWh}$ ).

\section{Discussion}

The temperature of ambient air at the EAHE outlet was calculated with the use of two methods based on theoretically determined ground temperatures.
Theoretical models produced higher air temperatures at the EAHE outlet than the experimentally measured temperatures. The operating conditions of the EAHE were identical in the applied models (pipe length, pipe depth, air flow rate), but in the calculations based on standard PN-EN 15241:2011 [16], the average hourly temperature at the EAHE outlet was $1.21^{\circ} \mathrm{C}$ higher on average than that measured in the experiment. The values calculated according to the method proposed by Popiel and Wojtkowiak [23] were $2.30^{\circ} \mathrm{C}$ higher on average.

It should also be noted that experimentally measured temperatures were characterized by low daily variations. The average daily difference between the maximum and minimum average hourly temperature at the EAHE outlet was determined at $1.54 \mathrm{~K}$. The most extreme and sporadic difference of $6.12 \mathrm{~K}$ was registered on 1 October. In the theoretical models, the temperature at the EAHE outlet was influenced primarily by ground temperature, which remains fairly stable throughout the day. The above led to the absence of hourly fluctuations in the daily temperature cycle.

\section{Conclusions}

The theoretical calculations modeling the distribution of ground temperature produced higher heat gains than the calculations performed based on the experimental data. In all analyzed cases, the theoretically modeled monthly heat gains were $29 \%$ higher on average than the measured heat gains. Greater differences were observed in cases 4 and 5, where the temperature of ambient air was based on TMY data. Heat gains were $34 \%$ higher on average than the measured results, whereas in cases 2 and 3, which were based on measured temperatures, monthly heat gains were higher by $23 \%$ on average than in case 1 . The above can be attributed to the fact that air temperatures based on TMY data were lower than the measured values. The observed differences were greater in winter (December) than in fall (October, November).

Further research is needed to evaluate the performance of an EAHE under real-life conditions and to investigate a theoretical models' tendency to overestimate heat gains in fall and winter.

\section{Conflict of Interest}

The authors declare no conflict of interest.

\section{References}

1. DE JESUS FREIRE A., ALEXANDRE J.L.C., SILVA V.B., COUTO N.D., ROUBOA A. Compact buried pipes 
system analysis for indoor air conditioning. Applied Thermal Engineering, 51 (1-2), 1124, 2013.

2. DE PAEPE M., JANSSENS A. Thermo-hydraulic design of earth-air heat exchangers. Energy and Buildings, 35 (4), 389, 2003.

3. HWANG S., OOKA R., NAM Y. Evaluation of estimation method of ground properties for the ground source heat pump system. Renewable Energy, 35 (9), 2123, 2010.

4. HWANG S., OOKA R., NAM Y. Evaluation of estimation method of ground properties for the ground source heat pump system. Renewable Energy, 35 (9), 2123, 2010.

5. KUMAR R., SINHA A.R., SINGH B.K., MODHUKALYA U. A design optimization tool of earth-to-air heat exchanger using a genetic algorithm. Renewable Energy, 33 (10), 2282, 2008.

6. CUCUMO M., CUCUMO S., MONTORO L., VULCANO A. A one-dimensional transient analytical model for earthto-air heat exchangers, taking into account condensation phenomena and thermal perturbation from the upper free surface as well as around the buried pipes. International Journal of Heat and Mass Transfer, 51 (3-4), 506, 2008.

7. KUMAR R., KAUSHIK, S. C., GARG S. N. Heating and cooling potential of an earth-to-air heat exchanger using artificial neural network. Renewable Energy, 31 (8), 1139, 2006.

8. BANSAL V., MISRA R., AGRAWAL G.D., MATHUR J. Performance analysis of earth-pipe-air heat exchanger for winter heating. Energy and Buildings, 41 (11), 1151, 2009.

9. BANSAL V., MISRA R., AGARWAL G.D., MATHUR J. Transient effect of soil thermal conductivity and duration of operation on performance of Earth Air Tunnel Heat Exchanger. Applied Energy, 103, 1, 2013.

10. GAN G. Simulation of dynamic interactions of the earth-air heat exchanger with soil and atmosphere for preheating of ventilation air. Applied Energy, 158, 118, 2015.

11. TITTELEIN P., ACHARD G., WURTZ E. Modelling earth-to-air heat exchanger behaviour with the convolutive response factors method. Applied Energy, 86 (9), 1683, 2009.

12. SKOTNICKA-SIEPSIAK A., WESOŁOWSKI M., PIECHOCKI J. Experimental and Numerical Study of an Earth-to-Air Heat Exchanger in Northeastern Poland, Pol. J. Environ. Stud. 27, No. 3, 2018.

13. OZGENER L. A review on the experimental and analytical analysis of earth to air heat exchanger (EAHE) systems in Turkey. Renewable and Sustainable Energy Reviews, 15 (9), 4483, 2011.

14. BISONIYA T.S., KUMAR A., BAREDAR P. Experimental and analytical studies of earth-air heat exchanger (EAHE) systems in India: a review. Renewable and Sustainable Energy Reviews, 19, 238, 2013.

15. RAMÍREZ-DÁVILA L., XAMÁN J., ARCE J., ÁLVAREZ G., HERNÁNDEZ-PÉREZ I. Numerical study of earth-to-air heat exchanger for three different climates. Energy and Buildings, 76, 238, 2014.

16. PN-EN 15241:2011, Ventilation for buildings - Calculation methods for energy losses due to ventilation and infiltration in commercial buildings.

17. PHETTEPLACE G., BAHNFLETH D., MILDENSTEIN P., OVERGAARD J., RAFFERTY K., WADE D.W. District heating guide. Atlanta, ASHRAE, 2013.

18. PERETTI C., ZARRELLA A., DE CARLI M., ZECCHIN $\mathrm{R}$. The design and environmental evaluation of earth-to-air heat exchangers (EAHE). A literature review. Renewable and Sustainable Energy Reviews, 28, 107, 2013.
19. OZGENER O., OZGENER L., TESTER J.W. A practical approach to predict soil temperature variations for geothermal (ground) heat exchangers applications. International Journal of Heat and Mass Transfer, 62, 473, 2013.

20. BADACHE M., ESLAMI-NEJAD P., OUZZANE M., AIDOUN Z., LAMARCHE L. A new modeling approach for improved ground temperature profile determination. Renewable Energy, 85, 436, 2016.

21. TITTELEIN P., ACHARD G., WURTZ E. Modelling earth-to-air heat exchanger behaviour with the convolutive response factors method. Applied Energy, 86 (9), 1683, 2009.

22. BIERNACKA B. Semi-empirical formula for the natural ground temperature distribution in Bialystok city region. Budownictwo i Inżynieria Środowiska, 1, 5, 2010.

23. POPIEL C.O., WOJTKOWIAK J. Temperature distributions of ground in the urban region of Poznan City. Experimental Thermal and Fluid Science, 51, 135, 2013.

24. MIHALAKAKOU G., LEWIS J. O., SANTAMOURIS M. The influence of different ground covers on the heating potential of earth-to-air heat exchangers. Renewable Energy, 7 (1), 33, 1996.

25. BREESCH H., BOSSAER A., JANSSENS A. Passive cooling in a low-energy office building. Solar Energy, 79, (6), 682, 2005.

26. BENHAMMOU M., DRAOUI B. Parametric study on thermal performance of earth-to-air heat exchanger used for cooling of buildings. Renewable and Sustainable Energy Reviews, 44, 348, 2015.

27. SKOTNICKA-SIEPSIAK A., WESOŁOWSKI M., PIECHOCKI J. Experimental and Numerical Study of an Earth-to-Air Heat Exchanger in Northeastern Poland, Pol. J. Environ. Stud. 27, No. 3, 2018.

28. BORDOLOI N., SHARMA A., NAUTIYAL H., GOEL V. An intense review on the latest advancements of Earth Air Heat Exchangers. Renewable and Sustainable Energy Reviews, 89, 261, 2018.

29. ARESTI L., CHRISTODOULIDES P., FLORIDES G. A review of the design aspects of ground heat exchangers. Renewable and Sustainable Energy Reviews, 92, 757, 2018.

30. ROUAG A., BENCHABANE A., MEHDID C.E. Thermal design of Earth-to-Air Heat Exchanger. Part I a new transient semi-analytical model for determining soil temperature. Journal of Cleaner Production, 182, 538, 2018.

31. YUSOF T.M., IBRAHIM H., AZMI W.H., REJAB M R.M. Thermal analysis of earth-to-air heat exchanger using laboratory simulator. Applied Thermal Engineering, 134, 130, 2018.

32. ESTRADA E., LABAT M., LORENTE S., ROCHA L.A. The impact of latent heat exchanges on the design of earth air heat exchangers. Applied Thermal Engineering, 129, 306, 2018.

33. RADIOTI G., SARTOR K., CHARLIER R., DEWALLEF P., NGUYEN F. Effect of undisturbed ground temperature on the design of closed-loop geothermal systems: A case study in a semi-urban environment. Applied energy, 200, 89, 2017.

34. KAYACI N., DEMIR H. Numerical modelling of transient soil temperature distribution for horizontal ground heat exchanger of ground source heat pump. Geothermics, , 73, 33, 2018. 